\title{
Quality of life, anxiety and depression in patients with chronic obstructive pulmonary disease
}

\author{
Qualidade de vida, ansiedade e depressão em pacientes com doença pulmonar obstrutiva crônica \\ Calidad de vida, ansiedad y depresión en pacientes con enfermedad pulmonar obstructiva crónica
}

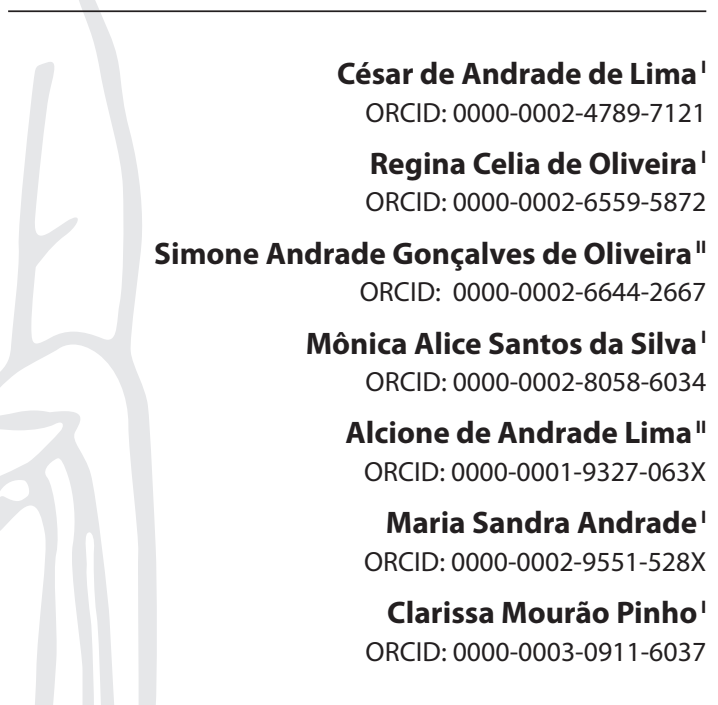

'Universidade de Pernambuco. Recife, Pernambuco, Brazil. "Secretaria Estadual de Saúde de Pernambuco. Recife, Pernambuco, Brazil.

How to cite this article: Lima CA, Oliveira RC, Oliveira SAG, Silva MAS, Lima AA, Andrade MS, et al. Quality of life, anxiety and depression in patients with chronic obstructive pulmonary disease. Rev Bras Enferm. 2020;73(Suppl 1):e20190423. doi: http://dx.doi.org/10.1590/0034-7167-2019-0423

\section{Corresponding author: \\ Maria Sandra Andrade \\ E-mail: sandra.andrade@upe.br}

EDITOR IN CHIEF: Antonio José de Almeida Filho ASSOCIATE EDITOR: Hugo Fernandes

Submission: 10-30-2019

Approval: 01-23-2020

\section{ABSTRACT}

Objective: to assess quality of life, anxiety and depression in patients with Chronic Obstructive Pulmonary Disease. Method: a cross-sectional, quantitative study, conducted in a reference hospital for the treatment of pulmonary diseases. Seventy patients were assessed, using a sociodemographic and clinical questionnaire, Beck's anxiety and Depression Inventories and the SF-36 Quality of Life Scale. Results: the participants had better quality of life in the vitality, mental health and social role functioning domains (median $=50.0$ ) and worse in limitation by physical and emotional role functioning (median $=0.0$ points). Anxiety, depression and oxygen dependence were associated with poorer results in the quality of life domains. Conclusion: all patients were classified with severe anxiety level and moderate depression predominance. Patients had low quality of life scores in all domains.

Descriptors: Chronic Obstructive Pulmonary Disease; Quality of Life; Anxiety; Depression; Nursing.

\section{RESUMO}

Objetivo: verificar a qualidade de vida, ansiedade e depressão em pacientes com Doença Pulmonar Obstrutiva Crônica. Método: trata-se de um estudo transversal, quantitativo, desenvolvido em hospital de referência no tratamento de doenças pulmonares. Foram avaliados 70 pacientes, utilizando-se um questionário sociodemográfico e clínico, inventário de ansiedade e depressão de Beck e a escala de qualidade de vida SF-36. Resultado: os participantes apresentaram melhor qualidade de vida nos domínios vitalidade, saúde mental e aspecto social (mediana $=50,0$ ) e pior avaliação em limitação por aspectos físicos e emocionais (mediana $=0,0$ pontos). Ansiedade, depressão e dependência de oxigênio estiveram associadas a piores resultados nos domínios de qualidade de vida. Conclusão: todos os pacientes foram classificados com nível grave de ansiedade e predominância de níveis moderados de depressão. Na avaliação da qualidade de vida os pacientes apresentam baixos escores em todos os domínios analisados.

Descritores: Doença Pulmonar Obstrutiva Crônica; Qualidade de Vida; Ansiedade; Depressão; Enfermagem.

\section{RESUMEN}

Objetivo: Estudiar la calidad de vida, ansiedad y depresión em pacientes con Enfermedad Pulmonar Obstructiva Crónica. Método: Se trata de un estudio transversal, cuantitativo, desarrollado en un hospital de referencia para el tratamiento de enfermedades pulmonares. Fueron evaluados 70 pacientes, usando una encuesta socio demográfica y clínica, inventario de ansiedad y depresión de Beck y la escala de calidad de vida SF-36. Resultados: Los participantes presentaron mejor calidad de vida en los parámetros de: vitalidad, salud mental y aspecto social (mediana $=50,0$ ) y la peor evaluación fue relacionada a los aspectos físicos y emocionales. (mediana $=0,0$ pontos). Ansiedad, depresión y la dependencia de oxígeno, estuvieron asociados a los peores resultados en los parámetros de calidad de vida. Conclusión: Todos los pacientes fueron clasificados con un nivel grave de ansiedad y predominando los niveles moderados de depresión. Em la evaluación de la calidad de vida, los pacientes presentaron bajos niveles en todos los parámetros analizados.

Descriptores: Enfermedad pulmonar obstructiva, crónica; Calidad de vida; Ansiedad; Depresión; Enfermería. 


\section{INTRODUCTION}

Chronic Obstructive Pulmonary Disease (COPD) is a preventable and treatable respiratory disease. It is characterized by incapacitating the body to perform adequate gas exchange, which results in progressive dyspnea, either with or without associated secretion, which can compromise the performance of daily activities ${ }^{(1)}$. The disease is associated with prolonged exposure to lung irritants, such as air pollution, chemical products, and cigarette smoke, the latter being considered the main cause. It may also be related to alpha-1-antitrypsin deficiency ${ }^{(2)}$.

The populational ageing, associated with smoking, is estimated to increase the prevalence and deaths by the disease. In a study that analyzed the trends in standardized mortality rates due to diseases attributable to tobacco, a one-third decrease in deaths due to COPD was identified; however, this rate has shown a new trend of increase in the last three years of the series. Mortality from COPD is still the leading cause of tobacco-related death ${ }^{(3)}$. In addition to individual impacts, such as decreased quality of life, the disease is responsible for increased health care costs because patients experience recurrent exacerbations resulting in more frequent hospitalizations as the disease progresses ${ }^{(1)}$.

The main impact of COPD on the quality of life is related to shortness of breath, which has been described as one of the most important aspects of physical disability and the performance of daily activities. Dependence on oxygen therapy significantly compromises all domains of quality of life in COPD patients, with a $40 \%$ reduction in quality of life in those considered dependent ${ }^{(4)}$. On the other hand, in a one-year study with 200 patients with COPD using high-flow oxygen, a significant reduction in the number of disease exacerbations, hospitalizations, $\mathrm{PaCO}_{2}$, improvement in pulmonary function and preservation of quality of life were found ${ }^{(5)}$.

The inability to perform daily activities and dependence of family members to perform personal care and nutrition, in addition to compromising quality of life, can contribute to the occurrence of anxiety and depression ${ }^{(6)}$. Coexistence of depression and COPD has been reported in $27 \%$ to $79 \%$ of patients, and concomitance of COPD and anxiety disorders has been reported in $12 \%$ to $96 \%$. The association of these two conditions worsens physical fitness, impairs quality of life, causes more frequent use of medical care, and reduces medication adherence ${ }^{(7)}$. The correlation of anxiety disorders with respiratory diseases can subjectively worsen the disease symptoms, especially dyspnea or cough. This results in routine exacerbations, higher rates of hospital care, increased doses of bronchodilators, inhaled corticosteroids, antibiotics and incidence of adverse events ${ }^{(8)}$.

Depending on the degree of compromise, it may decrease the independence of individuals for activities of daily living, reflect negatively on conjugal, family, and sexual relationships, leading to psychic and social alterations, which makes it relevant to conduct studies that further explore this assessment and contribute to health professionals' ability to plan care for patients living with COPD effectively.

\section{OBJECTIVE}

To assess quality of life, anxiety, and depression in patients with Chronic Obstructive Pulmonary Disease.

\section{METHODS}

\section{Ethical aspects}

The ethical precepts of Resolution 466/2012 of the National Health Council were respected, and the research was approved by the Research Ethics Committee of Hospital Otávio de Freitas (HOF).

\section{Study design, period and location}

A cross-sectional, observational, analytical, with quantitative approach study, guided by the STROBE tool. The study was conducted between May and December 2018, in the Pneumology unit of a reference hospital for the treatment of pulmonary diseases in the city of Recife, Pernambuco, Brazil.

\section{Population or sample; inclusion and exclusion criteria}

During the study period, 203 patients diagnosed with pulmonary diseases were admitted to the Pneumology unit, 70 of whom were diagnosed with COPD, which constituted the population/ sample of this study. This number was due to the small rotation of beds, because these patients remain in the unit for long periods, especially those dependent on oxygen therapy. All patients of both genders admitted to the unit with a diagnosis of COPD for at least one year, who had been hospitalized for at least one week were included and those with cognitive alterations, neurological diseases or impairment of their general condition that made it impossible for them to participate in the interview were excluded. There were no refusals to participate and all patients signed a Consent Form.

\section{Study protocol}

The participants were approached and invited to participate in the study by the researchers themselves. After explanation of the main study objectives, reading and written consent to participate, the interviews were started in an individualized room. It should be noted that, for those using oxygen therapy, the interviews were conducted with the patient in their bed.

A sociodemographic and clinical questionnaire was used for data collection, and the variables age, gender, origin, marital status, education and religious affiliation, time since diagnosis, outpatient follow-up, previous hospitalizations, current length of stay, use of inhaled medications, minimal effort dyspnea, dependence on oxygen therapy, use of alcohol, cigarettes, other medications, and clinical diseases/manifestations related to COPD were investigated.

The Short Form Health Survey 36 (SF-36) was used to assess their quality of life. The SF-36 is an important tool for assessing quality of life, consisting of 36 items, which assess eight dimensions of health: physical functioning; physical role functioning; bodily pain; general health perceptions; mental health; emotional role functioning; social role functioning and vitality, thus providing eight different indicators ranging from zero to 100. The higher the score, the better the quality of life/health status ${ }^{(9-10)}$.

The Beck Depression Inventory (BDI) and the Beck Anxiety Inventory (BAI) were used to assess anxiety and depression. The 
BDI consists of 21 items, each with four alternatives, reflecting increasing degrees of depression severity. The BDI is classified into the following items: minimal (score 0-11), mild (score 12-19), moderate (score 20-35) and severe (score 36-63). BAl assesses aspects related to anxiety; it is also composed of 21 items, and classifies anxiety as minimum (score 0-10), light (score 11-19), moderate (score 20-30) and severe (score 31-63) $)^{(11)}$.

\section{Statistical results and analysis}

The primary data were saved in Microsoft Excel 2016 software spreadsheets, and analyzed using SPSS 18.0 software. Descriptive analysis of sociodemographic and clinical data was performed and the Chi-square test was applied for proportion comparison. For the depression (BDI) and anxiety (BAI) scores, the frequency distributions of the score classification were used and the Fisher Exact test was applied to compare the distribution of the two scores. For quality of life, the scores of each domain of the instrument were calculated and normality of the score was assessed using the Kolmogorov-Smirnov test.

After finding the non-normal distribution of the score in all domains, minimum, maximum, median and interquartile ranges were calculated. The comparison of quality of life, depression and anxiety scores between patients with and without minimal effort dyspnea and patients with and without dependence on $\mathrm{O}_{2}$ supplementation was obtained by applying the Mann-Whitney test. The Spearman correlation test was used to assess the correlation between anxiety and depression scores and the quality of life score. All conclusions were found considering a $5 \%$ significance level.

\section{RESULTS}

The sample $(n=70)$ consisted mostly of male patients, mean age $63.7 \pm 9.4$, with a minimum age of 39 years and a maximum age of 86 years. The proportion comparison test was significant for factors evaluated ( $p$ value $\leq 0.001$ ), indicating that the profile described is significantly the most prevalent among the patients evaluated (Table 1).

The patients had been diagnosed one to five years before (53; $75.7 \%$ ), most of them were followed up in an outpatient context, with a report of previous hospitalization. The current length of stay ranged from 7 to 365 days, with a mean of $30.6 \pm 54.3$. The proportion comparison test was significant for all factors evaluated, except for the time since diagnosis ( $p$ value $=0.211$ ).

Most patients reported no alcohol use $(68 ; 97.1 \%)$ and no current smoking (65; 92.9\%), but 65 (92.9\%) were ex-smokers. Only five (7.1\%) reported never having smoked. The duration of smoking ranged from 10 to 60 years, with a mean of $40.1 \pm 10.4$ years. They reported having stopped smoking between one and five years, 28 (43.1\%); 27 (41.5\%), six or more years, and ten (15.4\%) less than one year before. The most prevalent type of cigarette was the industrial one $(67 ; 95.7 \%)$ followed by the nonindustrial one or roll-your-own cigarettes ( $3 ; 4.3 \%)$. The amount of cigarettes per day ranged from 7 to 60 cigarettes, with a mean of $39.0 \pm 10.0$ cigarettes/day. The smoking load varied from 25 to 165 pack-years, with a mean of $81.3 \pm 27.6$. The use of illegal drugs was not reported.
Regarding the clinical manifestations of COPD, 65 (92.9\%) reported minimal effort dyspnea; $64(91.4 \%)$ had a dry cough; 37 (52.9\%) had a productive cough and 13 (18.6\%) were dependent on oxygen therapy. Regarding related comorbidities, 63 (90.0\%) had hypertension; 42 (60.0\%) had Diabetes Mellitus; 27 (38.6\%) had a history of pulmonary tuberculosis; 15 (21.4\%) had a history of pneumonia; 14 (20.0\%) had a diagnosis of asthma and lung cancer; and three (4.3\%) had bronchiectasis. The proportion comparison test was significant for all factors, indicating that the number of patients with these comorbidities and those who do not have them are similar, except for the history of tuberculosis ( $p$-value $=0.056)$, diabetes $(p$-value $=0.094)$, and productive cough ( $p$ value $=0.633$ )

Concerning the analysis of the level of depression and anxiety using BDI, 52 (74.3\%) patients had a moderate level of depression, $17(24.3 \%)$, severe a level and one (1.4\%) had as mild level. No patients were classified with a minimum level of depression. In this evaluation, the scores ranged from 18 points to 44 points, with a median of 30 and an interquartile range of 9.25 points. According to BAI, all patients had a severe anxiety level, with a minimum score of 34 points and a maximum score of 63 points.

Table 1 - Sociodemographic characterization of patients with chronic obstructive pulmonary disease. Recife, Pernambuco, Brazil, 2018

\begin{tabular}{|c|c|c|c|}
\hline Variables & $\mathbf{n}$ & $\%$ & $p$ value \\
\hline \multicolumn{4}{|l|}{ Gender } \\
\hline Female & 21 & 30.0 & \multirow{2}{*}{0.001} \\
\hline Male & 49 & 70.0 & \\
\hline \multicolumn{4}{|l|}{ Age } \\
\hline 39 tom59 years & 20 & 28.6 & \multirow{2}{*}{$<0.001$} \\
\hline 60 years or more & 50 & 71.4 & \\
\hline \multicolumn{4}{|l|}{ Origin } \\
\hline Recife & 23 & 32.9 & \multirow{4}{*}{$<0.001$} \\
\hline Metropolitan Region of Recife & 23 & 32.9 & \\
\hline Interior of state & 23 & 32.9 & \\
\hline Other state & 1 & 1.3 & \\
\hline \multicolumn{4}{|l|}{ Work activity } \\
\hline Unemployed & 7 & 10.0 & \multirow{6}{*}{$<0.001$} \\
\hline Retired & 37 & 52.9 & \\
\hline Social benefit & 14 & 20.0 & \\
\hline Employed & 3 & 4.3 & \\
\hline Self-employed & 7 & 10.0 & \\
\hline Other & 2 & 2.9 & \\
\hline \multicolumn{4}{|l|}{ Marital status } \\
\hline Single & 5 & 7.1 & \multirow{4}{*}{$<0.001$} \\
\hline Common-law & 2 & 2.9 & \\
\hline Married & 55 & 78.6 & \\
\hline Widower & 8 & 11.4 & \\
\hline \multicolumn{4}{|l|}{ Level of education } \\
\hline Illiterate & 4 & 5.7 & \multirow{5}{*}{$<0.001$} \\
\hline Literate & 2 & 2.9 & \\
\hline Elementary school & 33 & 47.1 & \\
\hline High school & 27 & 38.6 & \\
\hline Higher education & 4 & 5.7 & \\
\hline \multicolumn{4}{|l|}{ Religion } \\
\hline Catholic & 44 & 62.9 & \multirow{4}{*}{$<0.001$} \\
\hline Evangelical & 18 & 25.7 & \\
\hline None & 4 & 5.7 & \\
\hline Other & 4 & 5.7 & \\
\hline
\end{tabular}

Note: ${ }^{1} P$ value of the Chi-square test for comparison of proportions. 
Table 2 - Clinical characteristics of patients with chronic obstructive pulmonary disease, Recife, Pernambuco, Brazil, 2018

\begin{tabular}{|c|c|c|c|}
\hline Variables & $\mathbf{n}$ & $\%$ & $p$ value $^{1}$ \\
\hline \multicolumn{4}{|l|}{ Time since diagnosis } \\
\hline 1 a 2 years & 29 & 41.4 & \multirow{3}{*}{0.211} \\
\hline 3 a 5 years & 24 & 34.3 & \\
\hline 6 years or more & 17 & 24.3 & \\
\hline Minimum - Maximum & \multicolumn{2}{|c|}{$1.0-20.0$} & - \\
\hline Mean \pm Standard deviation & \multicolumn{2}{|c|}{$4.9 \pm 4.3$} & - \\
\hline \multicolumn{4}{|l|}{ Outpatient Follow-up } \\
\hline Yes & 56 & 80.0 & \multirow{2}{*}{$<0.001$} \\
\hline No & 14 & 20.0 & \\
\hline \multicolumn{4}{|l|}{ Previous hospitalization } \\
\hline Yes & 52 & 74.3 & \multirow{2}{*}{$<0.001$} \\
\hline No & 18 & 25.7 & \\
\hline \multicolumn{4}{|l|}{ Number of hospitalizations } \\
\hline Minimum - Maximum & \multicolumn{2}{|c|}{$1.0-7.0$} & - \\
\hline Mean \pm Standard deviation & \multicolumn{2}{|c|}{$2.6 \pm 1.3$} & - \\
\hline \multicolumn{4}{|l|}{ Inhalaed medications } \\
\hline Formoterol fumarate/ Budesonide & 10 & 14.3 & \\
\hline Formoterol fumarate/ Budesonide + tiotropium bromide & 31 & 44.3 & \\
\hline Salbutamol & 1 & 1.4 & \\
\hline $\begin{array}{l}\text { Salbutamol + Formoterol fumarate/ Budesonide + tiotropium } \\
\text { bromide }\end{array}$ & 18 & 25.7 & $<0.001$ \\
\hline Salbutamol + tiotropium bromide & 2 & 2.9 & \\
\hline Salbutamol + Formoterol fumarate / Budesonide & 7 & 10.0 & \\
\hline Fenoterol hydrobromide + Formoterol fumarate / Budesonide & 1 & 1.4 & \\
\hline
\end{tabular}

Table 3 - Descriptive analysis of the quality of life domains of patients with Chronic Obstructive Pulmonary Disease. Recife, Pernambuco, Brazil, 2018

\begin{tabular}{lcccc}
\hline Domain & Minimum & Maximum & Median & $\begin{array}{c}\text { Interquartile } \\
\text { range }\end{array}$ \\
\hline Physical functioning & 0.00 & 65.00 & 15.00 & 10.00 \\
Physical role functioning & 0.00 & 25.00 & 0.00 & 0.00 \\
Bodily pain & 0.00 & 54.00 & 41.00 & 2.50 \\
General health perceptions & 5.00 & 45.00 & 25.00 & 5.00 \\
Vitality & 10.00 & 70.00 & 50.00 & 5.00 \\
Social role functioning & 0.00 & 62.50 & 50.00 & 0.00 \\
Emotional role functioning & 0.00 & 33.33 & 0.00 & 0.00 \\
Mental health & 36.00 & 68.00 & 50.00 & 4.00 \\
\hline
\end{tabular}

Table 4 - Comparison of distribution of quality of life domains, depression and anxiety levels in patients with chronic obstructive pulmonary disease with minimal and medium effort dyspnea and dependence on oxygen therapy, Recife, Pernambuco, Brazil, 2018

\begin{tabular}{|c|c|c|c|c|c|c|}
\hline \multirow[t]{2}{*}{ Domain } & \multicolumn{2}{|c|}{$\begin{array}{l}\text { Minimal effort } \\
\text { dyspnea }\end{array}$} & \multirow[t]{2}{*}{$p$ value $^{1}$} & \multicolumn{2}{|c|}{$\begin{array}{c}\text { Dependent on } \\
0 \text {, therapy }\end{array}$} & \multirow[t]{2}{*}{$p$ value } \\
\hline & Yes & No & & Yes & No & \\
\hline Capacidade funcional & $15.0(10.0)$ & $15.0(40.0)$ & 0.037 & $0.0(2.5)$ & $15.0(5.0)$ & $<0.001$ \\
\hline Limitação por aspectos físicos & $0.0(0.0)$ & $0.0(0.0)$ & 0.782 & $0.0(0.0)$ & $0.0(0.0)$ & 0.633 \\
\hline Dor & $41.0(5.0)$ & $41.0(5.5)$ & 0.564 & $31.0(10.0)$ & $41.0(0.0)$ & 0.051 \\
\hline Estado de saúde geral & $25.0(5.0)$ & $30.0(20.0)$ & 0.450 & $25.0(5.0)$ & $25.0(10.0)$ & 0.010 \\
\hline Vitalidade & $50.0(7.5)$ & $50.0(32.5)$ & 0.132 & $50.0(12.5)$ & $50.0(2.5)$ & 0.727 \\
\hline Aspecto social & $50.0(0.0)$ & $50.0(18.8)$ & 0.657 & $37.5(18.8)$ & $50.0(0.0)$ & $<0.001$ \\
\hline Aspecto emocional & $0.0(0.0)$ & $0.0(0.0)$ & 0.693 & $0.0(0.0)$ & $0.0(0.0)$ & 0.496 \\
\hline Saúde mental & $48.0(4.0)$ & $52.0(18.0)$ & 0.287 & $48.0(8.0)$ & $52.0(4.0)$ & 0.278 \\
\hline BDI (Depressão) & $30.0(10.0)$ & $27.0(11.0)$ & 0.398 & $38.0(8.5)$ & $29.0(8.5)$ & 0.001 \\
\hline BAI (Ansiedade) & $49.0(7.0)$ & $45.0(12.0)$ & 0.039 & $56.0(16.5)$ & $48.0(5.5)$ & 0.027 \\
\hline
\end{tabular}

Note: ${ }^{\prime}$ Mann-Whitney test (if $p$ value $<0.05$ there is a difference between the groups). (-) no interquartile range; $B D I=B e c k$ Depression Inventory; BAI = Beck Anxiety Inventory.
The median level of anxiety was 48.5 points, with an interquartile range of 8.0 points. When comparing the classification of depression and anxiety, as well as the distribution of the depression and anxiety scores, there was a significant difference ( $p$ value $<0.001$ ) for both comparisons.

In the assessment of quality of life, better scores in in vitality, mental health and social role functioning (median=50.0 points) were found and lower scores in physical and emotional role functioning (median $=0.0$ points) (Table 3).

When comparing quality of life, level of depression and anxiety for patients with minimal effort dyspnea, a difference between groups of patients who have and who do not have such dyspnea was found in the areas of Physical functioning and anxiety. The groups of patients with and minimal effort without dyspnea had the same median Physical functioning domain, but the interquartile range was higher in the group of patients without dyspnea (40.0), indicating that there are people with a significantly higher Physical functioning score ( $p$ value $=0.037$ ) in this group. The median anxiety level was higher in the group of patients with minimal effort dyspnea and this difference was significantly higher than in the group without dyspnea ( $p$ value $=0.039$ ).

When comparing the groups with and without dependence on oxygen therapy, the group of patients without dependence on oxygen therapy had a significantly higher distribution in the domains of quality of life, Physical functioning, General health perceptions and Social role functioning. The median levels of depression and anxiety were higher median in the group of patients dependent on oxygen therapy.

Regarding the correlation between quality of life and the level of depression and anxiety, depression showed a significant and inversely proportional correlation with the following quality of life domains: Physical functioning, Bodily pain, vitality, Social role functioning and Mental health. As for anxiety, a significant and inversely proportional correlation was found with the following domains: Physical functioning, Bodily pain, Social role functioning and Mental health.

\section{DISCUSSION}

In this study, there was a predominance of male patients, older adults, retired or those with a social benefit, married, with elementary or high school education, Catholic or 
Table 5 - Correlation analysis of the quality of life domains with the score of depression and anxiety in patients with Obstructive Pulmonary Disease, Recife, Pernambuco, Brazil, 2018

\begin{tabular}{lcc}
\hline \multirow{2}{*}{ Domain } & \multicolumn{2}{c}{ Factors assessed } \\
& BDI (Depression) & BAI (Anxiety) \\
\hline Physical functioning & $\rho=-0.478 ; p<0.001^{1}$ & $\rho=-0.356 ; p=0.003^{1}$ \\
Physical role functioning & $\rho=-0.021 ; p=0.864$ & $\rho=-0.027 ; p=0.825$ \\
Bodily pain & $\rho=-0.362 ; p=0.002^{1}$ & $\rho=-0.264 ; p=0.027^{1}$ \\
General health perceptions & $\rho=-0.195 ; p=0.105$ & $\rho=-0.143 ; p=0.237$ \\
Vitality & $\rho=-0.250 ; p=0.037^{1}$ & $\rho=-0.008 ; p=0.950$ \\
Social role functioning & $\rho=-0.533 ; p<0.001^{1}$ & $\rho=-0.354 ; p=0.003^{1}$ \\
Emotional role functioning & $\rho=-0.011 ; p=0.930$ & $\rho=-0.038 ; p=0.753$ \\
Mental health & $\rho=-0.308 ; p=0.009^{1}$ & $\rho=-0.429 ; p<0.001^{1}$
\end{tabular}

Note: $\rho=$ Correlation coefficient. 'significant $p$ value, Spearman test at $5 \% ; B D I=$ Beck Depression Inventory; $B A I=$ Beck Anxiety Inventory.

Evangelical. The relationship between male gender and COPD is well established, because men have greater exposure to smoking and to irritating chemical agents. However, a change in this profile has been identified in recent years, with an increase in the number of women who smoke, with more severe disease and higher mortality rates when compared to men ${ }^{(12)}$.

Most of the interviewees had a recent COPD diagnosis, were followed in the Pneumology clinic, with a history of previous hospitalizations and a long length of hospitalization. The planning of strategies to deliver care to individuals and family members should be initiated during hospital stay, considering the health care network. The focus of care should be the outpatient clinic, which must be qualified and integrated with health promotion and prevention actions. In this perspective, guarantees are required, such as access, welcoming, humanized care, respect for diversities, and the adoption of user-centered care performed by multiprofessional teams ${ }^{(1)}$.

When planning outpatient care, the health care professionals must be attentive to aspects related to health education, in a selfcare learning perspective, according to the reality experienced by each one of the patients. In this sense, health care professionals, especially nurses, should analyze their role as educators critically, considering that education is a form of intervention on a reality. Thus, dialogue, the reality of users' lives, their knowledge and experiences must be valued in order to developed limits and possibilities in the coexistence with a chronic disease ${ }^{(13)}$. The absence or gaps of care from this perspective is a great loss for the patient and the health service.

Care planning for these patients is required in order to avoid hospitalizations, because a long hospital stay may contribute to exposure to new infections, worsen anxiety and depression symptoms and increase the costs to the health system. A national study evaluating the hospitalization rate and costs associated with COPD found that the units that implemented tiotropium bromide as standard treatment of the disease had a decrease in costs and a $52 \%$ reduction in the number of hospitalizations when compared to those that did not have the standard medication ${ }^{(14)}$.

Another important factor that should be considered when planning care provided to patients and their families is the smoking habit. Almost all members of this study were previous smokers, with a high mean consumption of cigarettes/day and a high smoking load. The relationship between smoking and COPD is well established, although there is no standardized classification criterion about smoking load. In national studies that assessed the smoking load in patients with the disease, values were lower than those found in this study. Age and smoking load were considered risk factors for the development of the disease ${ }^{(15-16)}$.

Most patients reported coughing. Despite the report of dyspnea, only a small percentage was dependent on oxygen therapy. These findings highlight other aspects that should be considered in care planning, which are social, psychological and family relationships. In this sense, dyspnea and cough may contribute to the limitation of patients in performing their activities of daily living, affecting their social and family relationships, compromising their quality of life and favoring changes in emotional aspects of the individual(17).

Long-term oxygen therapy can improve quality of life, as it improves the dyspnea-related symptoms ${ }^{(18)}$. It is important to emphasize that patients frequently remain hospitalized only for oxygen therapy, given that the health system does not offer home care and such problem ends up negatively impacting the patient's physical and mental health, as well as generating a burden on the health care system. In this perspective, the importance of home care planning for patients who require the use of long-term oxygen is emphasized.

Almost all participants had moderate to severe depression levels and were classified with severe anxiety. Moreover, being hospitalized for several days far from the family is a factor that can aggravate such variables. It is extremely important that links are created between the professional and the patient so that the health care professional can offer support to the patient and mobilize mechanisms to confront his/her health condition. Strengthening self-confidence and providing support for adapting to new lifestyles and overcoming feelings of helplessness and hopelessness can contribute to the planning of care that will enable a better quality of life for people living with $\mathrm{COPD}^{(7)}$.

The assessment of quality of life showed that all COPD patients had low scores in all analyzed domains. Physical functioning, Physical role functioning and Emotional role functioning were those with the lowest scores, with Physical and Emotional role functioning scoring zero points. These results should be carefully considered because this study has a predominance of anxious and depressive individuals. Anxiety and depression can influence aspects related to all quality of life domains. It has been shown that impairment of quality of life is a predictor of mortality of COPD patients, and quality of life can be affected by dyspnea ${ }^{(19)}$.

The relationship between clinical aspects and the domains Physical functioning and Physical role functioning was found, since the disease causes limitations, depending on the degree of functional pulmonary impairment. Significant associations were found between minimal effort dyspnea and Physical functioning and between dyspnea and anxiety. There was significant association between absence of dependence on oxygen therapy and Physical functioning, General health perceptions, Social role functioning, thereby showing that those who were not dependent had a better quality of life.

A previous study that assessed the relationship between anxiety and depression in patients with COPD showed that more than half (53.3\%) of respondents had anxiety, classified as mild 
or moderate, and $45.4 \%$ symptoms of depression, ranging from moderate to severe. The frequency of anxiety and depression symptoms is higher in patients with effort-driven limitations due to shortness of breath. Depression was predominant in those who used medication, with low functional capacity and limitation of activities due to dyspnea. No difference was observed for anxiety and depression in those with initial or advanced COPD. It was also found that acute exacerbations have a great impact on the emotional well-being of those living with the disease ${ }^{(20)}$.

In addition, symptoms of depression and anxiety were also related to the increase in the number of hospital readmissions, and were considered as risk factors ${ }^{(21)}$. Minimal effort dyspnea is associated with worse quality of life scores in all domains, influencing daily activities, such as the increased number of hospitalizations ${ }^{(22)}$. Regarding the correlation between depression and anxiety and quality of life domains, it was found that the higher the depression and anxiety, the lower the quality of life domain scores, which corroborates the perception that these aspects are directly related. However, it is important to understand the clinical aspects experienced by the patient, the length of stay and the distance from social and family life, which can further aggravate the Emotional role functioning and quality of life of these individuals ${ }^{(23)}$.

In this context, anxiety and depression are risk factors for clinical exacerbations in patients with COPD and, in turn, can compromise the quality of life. These patients have a worse prognosis, especially when related to disabilities in performing activities of daily living and dependence on oxygen therapy. These conditions affect their social and family life and there is a tendency to isolation and disbelief regarding treatment as the disease progresses which reinforces the importance of creating a bond and a greater therapeutic follow-up by a multidisciplinary team ${ }^{(24)}$.

\section{Study limitations}

The limitation of this study is related to the length of hospitalization of patients in the unit, which has an impact on the low turnover of beds, reflecting on the sample size. In addition, this study was conducted only with individuals admitted to a single hospital. Thus, the results should not be interpreted in a generalized manner, but rather, analyzed with the intention of substantiating care aiming at improving the quality of life of these patients.

\section{Contributions to the nursing area, health or public policy}

Greater engagement of nurses in outpatient services is necessary, the establishment of nursing appointments focused on the Nursing Process being of extreme importance. Also, the development and implementation of health education strategies are required in order to increase and correct the use of inhaled medications, by outlining a better nursing care, making it possible that interventions are aimed towards risk factors and those factors that promote the quality of life of these individuals.

\section{CONCLUSION}

All patients were classified as having severe anxiety with a predominance of moderate levels of depression. In the assessment of quality of life, all patients had low scores in all domains. Physical functioning, Physical role functioning and Emotional role functioning were those with the lowest scores. The correlation between quality of life and the levels of depression and anxiety showed that depression is correlated with Physical functioning, Bodily pain, Vitality, Social role functioning and Mental health, and anxiety is correlated with Physical functioning, Bodily pain, Social role functioning and Mental health.

\section{REFERENCES}

1. Global Initiative for Chronic Obstructive Lung Disease. Global strategy for the diagnosis, management, and prevention of Chronic Obstructive Pulmonary Disease (2019 Report). Wisconsin: GOLD; 2018.

2. Gendron LM, Nyberg A, Saey D, Maltais F, Lacasse Y. Active mind-body movement therapies as an adjunt to or in comparison with pulmonary rehabilitation for people with chronic obstructive pulmonary disease. Cochrane Data base Systc Rev. 2018;10:CD012290. doi: 10.1002/14651858. CD012290.pub2

3. José BPS, Corrêa RA, Malta DC, Passos VMA, França EB, Teixeira RA, Camargos PAM. Mortality and disability from tobacco-related diseases in Brazil, 1990 to 2015. Rev Bras Epidemiol. 2017;20 (Suppl. 1):75-89. doi: 10.1590/1980-5497201700050007

4. Lacasse Y, Bernard S, Martin S, Boivin M, Maltais F. Utility scores in Patients with oxygem-dependent COPD: a case controle study. J Chronic Ostructive Pulmon Dis. 2015;12(5):510-515. doi: 10.3109/154112555.2014.995290

5. Storgaad LH, Hockey H, Laursen BS, Weinreich UM. Long-term effects of oxigen-enriched high-flow nasal cannula treatment in COPD patients with chronic hypoxemic respiratory failure. Clinical Trial Report. 2018;13:1195-1205. doi: 10.2147/COPD.S159666

6. Jarab A, Alefishat E, Mukattash T, Alzoubi K, Pinto S. Patient's perspective of the impact of COPD on quality of life: a focus group study for patients with COPD. Int J Clin Pharm. 2018;40(3):573-9. doi: 10.1007/s11096-018-0614-z

7. Godoy RF. Anxiety, depression and hopelessness in patients with Chronic Obstructive Pulmonary Disease (COPD). Estud Pesq Psicol [Internet]. 2013 [cited 2019 Feb 15];13(3):1089-102. Available from: http://pepsic.bvsalud.org/pdf/epp/v13n3/v13n3a15.pdf

8. Uchmanowicz I, Jankowska-Polanska B, Motowidlo U, Uchmanowicz B, Chabowski M. Assessment of illness acceptance by patients with COPD and the prevalence of depression and anxiety in COPD. Int J Chron Obstruct Pulmon Dis [Internet]. 2016 [cited 2019 Feb 16];1 1:963-70. Available from: https://doi.org/10.2147/COPD.S102754

9. Ware JE, Sherbourne CD. The MOS 36-Item Short Form Health Survey (SF-36): I. Conceptual framework and item selection. Med Care [Internet]. 
2015 [cited 2019 Jan 18];30(6):473-83. Available from: https://pdfs.semanticscholar.org/06cb/0076e310136d0ca8b56cc8585ec2bf43e029.pdf

10. Ciconelli RM, Ferraz MB, Santos W, Meinão I, Quaresma MR. Tradução para a língua portuguesa e validação do questionário genérico de avaliação de qualidade de vida SF-36 (Brasil SF-36). Rev Bras Reumatol [Internet]. 2015 [cited 2019 Jan 18];39(3):143-50. Available from: http://www.luzimarteixeira.com.br/wp-content/uploads/2011/04/validacao-sf-36-brasildoc.pdf

11. Cunha JA. Manual da versão em português das Escalas Beck. São Paulo: Casa do Psicólogo; 2001.

12. Kokturk N, Kilic H, Baha A, Lee SD, Jones PW. Sex Difference in Chronic Obstructive Lung Disease. Does it Matter? A Coincise Review [Internet]. 2016 [cited 2019 Fev 16]; 13(6):799-806. Available from: https://doi.org/10.1080/15412555.2016.1199666

13. Freire P. Pedagogia da autonomia: saberes necessários à prática educativa. São Paulo: Paz e Terra; 1996. 144 p.

14. Melo TG, Santoni NB, Finkelstein BJ, Veiga DLP, Nascimento MHS, Rosito FCA. Índice de hospitalização e custos associados à Doença Pulmonar Obstrutiva Crônica (DPOC) entre estados que padronizam vesus que não padronizam o tiotrópio - dados do mundo real. J Bras Econ Saúde [Internet]. 2018 [cited 2019 Mar 16];10(1):29-35. Available from: http://docs.bvsalud.org/biblioref/2018/05/884392/jbes101doi-1021115_jbesv10n1p29-35.pdf

15. Kopitovic I, Bokan A, Andrijevic I, llic M, Marinkovic S, Milicic D, Vukoja M. Frequency of COPD in health care workers who smoke. J Bras Pneumol. 2017;43(5):351-6. doi: 10.1590/s1806-37562017000000028

16. Caram LMO, Ferrari R, Naves CR, Coelho LS, Vale SA, Tanni SE, Godoy I. Risk factors for cardiovascular disease in patients with COPD: mild-tomoderate COPD versus severe-to-very severe COPD. J Bras Pneumol. 2016;42(3):179-84. doi: 10.1590/S1806-37562015000000121

17. Soler-Cataluña JJ, Sauleda J, Valdés L, Marín P, Agüero R, Pérez M, et al. Prevalencia y percepción de la variabilidade diária de los sintomas em pacientes com enfermedad pulmonar obstructiva crónica estable em España. Arch Bronconeumol. 2016;52(6):287-344. doi: 10.1016/j. arbres.2015.11.010

18. Mesquita CB, Knaut C, Caram LMO, Ferrari R, Bazan SGZ, Godoy I, Tanni SE. Impact of adherence to long-term oxygen therapy on patients with COPD and exertional hypoxemia followed for one year. J Bras Pneumol. 2018;44(5):390-7. doi: 10.1590/s1806-37562017000000019

19. Akinci B, Aslan GK, Kiyan E. Sleep quality and quality of life in patients with moderate to very severe chronic obstructive pulmonar disease. Clin Respir J [Internet]. 2018 [cited 2019 Mar 25]; 12(4):1739-46. Available from: https://doi.org/10.1111/crj.12738

20. Jacome C, Marques A, Gabriel R, Cruz J, Figueiredo D. Anxiety and depression in Portuguese patients with chonic obstructive pulmonar disease: a multicenter cross-sectional study. Rev Port Med Geral Fam [Internet]. 2015 [cited 2019 Feb 18];31(1):24-32. Available from: http:// www.scielo.mec.pt/pdf/rpmgf/v31n1/v31n1a04.pdf

21. Iyer AS, Bhatt SP, Garner JJ, Wells JM, Trevor JL, Patel NM, et al. Depression in associated with readmission for acute Exacerbation of Chronic Obstructive Pulmonary Disease. Ann Am Thorac Soc. 2016;13(2):197-203. doi: 10.1513/AnnalsATS.201507-4390C

22. Gruenberger JB, Vietri J, Keininger DL, Mahler DA. Greater dyspnea is associated with lower health-related quality of life among European patients with COPD. Int J Chron Obstruct Pulmon Dis. 2017;12:937-44. doi: 10.2147/COPD.S123744

23. Miravitlles M, Ribera A. Understanding the impact of symtoms on the burden of COPD. Resp Res. 2017;18(67):119-29. doi: 10.1186/ s12931-017-0548-3

24. Kruis AL, Soljak M, Chavannes NH, Elkin SL. COPD Multidisciplinary team meeting in the United Kingdom: health care professionals' perceptions of aims and structure. COPD. 2016;13(5):639-41. doi: 10.3109/15412555.2015.1007930 